\title{
Thyroperoxidase Antibody Measurement
}

National Cancer Institute

\section{Source}

National Cancer Institute. Thyroperoxidase Antibody Measurement. NCI Thesaurus.

Code C96638.

The determination of the amount of thyroperoxidase antibody present in a sample. 